\title{
DEVELOPING ESP READING COMPREHENSION INSTRUCTIONAL MATERIALS THROUGH SCHEMA THEORY APPROACH AT PAI STUDY PROGRAM OF TARBIYAH FACULTY OF IAIN BENGKULU
}

\author{
Syamsul Rizal \\ State Institute for Islamic Studies of Bengkulu, Indonesia \\ syamsul.rizal42@gmail.com
}

\begin{abstract}
The fact that the English reading comprehension ability of the students of Islamic Religious Education of Tarbiyah Faculty of IAIN Bengkulu is still low. One of the causes of the problem is the ineffectiveness of the English teaching materials that have been used. Therefore, the purpose of this study is to produce ESP English reading comprehension instructional materials based on Islamic Educational Studies (IES) in accordance with the characteristics of Islamic Education Study Program students of Tarbiyah Faculty. The procedure in developing this instructional materials was adapted from Borg and Gall's research and development model. The research method used to investigate the effectiveness of the product is quasi-experimental method. The developed instructional material prototype was validated by material and media experts and also by English lecturers. According to experts of material and media, the product is very good with the percentage of ideality of $76 \%$ and $73.3 \%$. According to the English lecturers' validations are also categorized in good category with $77.5 \%$ percentage and the students' responses from the aspect of material, presentation and language assessment are classified as positive (good) category. There is a significant difference of reading comprehension achievement between experimental and control group students. It means that the students' reading comprehension ability in the experimental group is higher than that of in the control group. It indicates that the product of this research is effective in improving the students' English reading comprehension achievement.
\end{abstract}

Keywords: reading comprehension, islamic studies, instructional materials, ESP

\section{INTRODUCTION}

The main objective of teaching English I, II and III as General Basic Course(MKDU) based on the course syllabus of Tarbiyah Faculty of IAIN Bengkulu is that students have the ability to comprehend English reading text, English vocabulary and English grammar. Generally, it can be seen that any topic of discussion in all English instructional materials used as text books in teaching English I, II. And III for the students of STAIN, IAIN, and UIN in Indonesia is always started with the reading text followed by some English vocabulary contained in the reading text and then it must be translated into Indonesian. Further discussion of the material is the discussion on grammar with the examples of grammatical sentences written in the previous reading text.

Based on the observation and interview with the English lecturers of IAIN Bengkulu, the researcher found that teaching reading comprehension needs a lot of time because of the students' difficulty in comprehending the English text and thus it is required a long time to comprehend the reading text while the time allocation for the discussion of other parts such as the discussion of grammar is not comparable to the time allocation for the reading comprehension discussion. The students' difficulty in comrehending the English reading text could be observed when they wereasked to discuss the reading text they have read, they are mostly 
silent only and if they comprehended it, their comprehension is very limited about the content of the reading text.

In learning process, the reading comprehension ability is the key for the students to get success. Most of the students obtain knowledge through reading activities. The knowledge gained by the students is not only derived from the process of teaching and learning at their campus, but it also gained through the activity of reading in everyday life. Therefore, the ability to comprehend the reading texts is an important part in increasing the students' knowledge and experinece. According to Farr (1984:5), reading is the heart of education. The importance of reading activities as stated by Farr suggests that reading is a source of activity to acquire knowledge because by reading one can make the process of learning and reasoning. The same view as farr is also stated by Dupuis (1992:17) who stated that reading is a primary source of information in a learning situationbecause the information obtained from this activity can broaden the readers' knowledge view. Sharon (2002 ) as quoted by Abdillah states that $70 \%$ $95 \%$ of any teaching and learning activity in the classroom depends on written texts such as textbooks. Therefore, the students must be a good reader in order to comprehend what they read in the text.

Nowsday, the situation in teaching MKDU English course at IAIN Bengkulu based on the researcher's observations found: (1) many lecturers rely more on textbooks or instructional materials prepared by other lecturers, (2) the lecturers are less aware of the importance of instructional material preparation in accordance with their students' need, and (3) many lecturers haven't understood yet about the mechanism and technique on how to design and develop their instructional materials properly. The absence of English instructional material appropriate to the students' needs, especially students of non English Department of Tarbiyah Faculty at IAIN of Bengkulu is due to the lack of comprehensive study of the developing English teaching materials based educational Islamic studies with scientific instructional material design theories.

The developed instructional materials based on the instructional design theories play a very significant role in creating conducive teaching and learning process. At least, there are three reasons why the teaching material has a central position, namely (1) serving as a representation of teachers, (2) as a means of achieving learning goals, and (3) the optimization of service to learners (Zulkarnaini, 2009:5). Basically, MKDU English instructional material at IAIN of Bengkulu was published by Language Development Centre of IAIN of Bengkulu consisting of textbooks: English I, II, and III in which the revised content from English for General Purpose (ESP) into ESP approch based on Islamic studies reading texts, but the preparation of those English textbooks were merely compilations without doing students' need analysis and a variety of systemic and systematic process. It can not reach the real what students' need so those English instructional materials are delivered tend not to attract the learners' interest.

This research was focused on English II course and provided for PAI students There are three research questions raised in this study: (1) how is the perception of the third semester students of PAI Studi Program towards the English text book used as English teaching material now?, (2) how is the quality of the model of instructional material developed by the researcher according to the expert of teaching material, the expert of media, and English lecturers of IAIN of Bengkulu, and (3) how is the student 's response to the model of Islamic educational studies based reading instructional material developed by the researcher? 


\section{LITERATURE REVIEW}

\subsection{The Concept of Reading Comprehnsion}

The activity of reading is a factor that determines the success for anyone. Indeed the activity of reading is a part of language skills, in addition to listening, speaking, and writing skill. All the skill are basically interrelated with each other. The listening and reading skills are grouped on the receptive skills, while the speaking and writing skills are grouped into productive skills. Busching and Schwartz (1983:15) describes the relationship among those language skills as indicated in Figure 1 below.

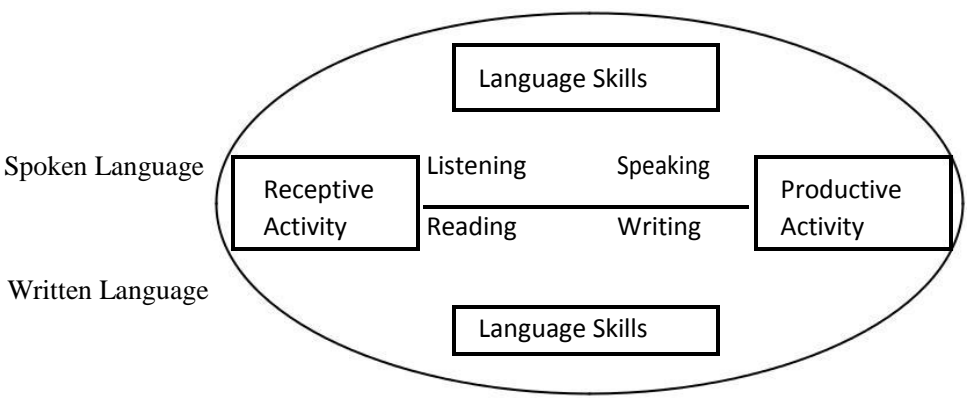

Figure 1. The Relationship among Language Skills

Based on figure 1 above, it can be understood that the use of language that is receptive (listening and reading) and productive (speaking and writing) can create a basic coherence. In academic skills receptive plays a very important role because the learning and teaching activity requires both students and lecturers to read a lot to be able to acquire knowledge. The knowledge gained through reading activity will be passed on to the productive activities through writing and speaking skills. Therefore, in the absence of the activity of reading, it will be very difficult to be able to convey ideas or thoughts through writing and speaking activities. ., The understanding of reading comprehension is described by some experts, for example, Nuttall ( 1996:40 ) states "Comprehension is understanding what has been read rather than spelling the words". Nuttall further define the term of reading, " ... reading as meaningful, interpretation of printed or written verbal symbols. It means that reading does the writer intend a result of interaction between the perception graphic symbols that represent language and readers language skills, cognitive skills and knowledge". From Nuttall statement, it can be explained that (1) the activity of reading is to comprehend what has been read from a reading text by the reader and in this case the activity of reading is not merely to spell or pronounce the words printed in texts, (2) the activity of reading is necessary to attempt to make sense and to interpret the symbols printed language in written form. In this case, the reader's cognitive knowledge or schemata are very helpful in accelerating the understanding of the texts they read..

In order to improve the students' reading comprehension of English reading texts, it is needed for all English lecturers of IAIN Bengkulu to master several efective approaches in teaching reading comprehension. One ofthe proper approaches in teaching reading comprehension is schema theory approaches. Schema theory is a theory which states that reading is an interactive communication process that involves background knowledge, language, and the idea of an organization (Harjasujana in Indrawati, 1996). To be able to comprehend the content of any reading text well, readers need background knowledge related to the 
reading material they read. With such assistance, the reader can interpret the author's intent.

The application of schema theory in teaching reading comprehension involves three stages, namely: pre reading, while reading, and post reading. In the first stage, the activities carried out are activating students' prior knowledge related to the content of reading text to be discussed. The second step is the activity in which the lecturer provide or insert some questions. The third step is the activity to provide repetition, feedback, and cognitive stimulation.

Richards (1985:238) states thatt the level of reading comprehension can be divided into four, namely literal comprehension, inferential comprehension, critical understanding or valuation, appreciation. At the literal level of comprehension, readers are required to be able to understand, remember, or repeat with clear information about the content of the reading passage. In inferential comprehension, readers are required to obtain information from a reading text that is not so obvious to use their instinct and experience and to make a conclusion. At the critical level of understanding, readers are required to be able to make sense of written language.

The question in reading the understanding used in this study refers to the formulation developed by Sharpe in the Baron's TOEFL. Sharpe (2004:316) identifies five types of questions commonly used in reading tests. The 5 types of questions are: (1) questions for knowing main ideas, (2) vocabulary questions in context (using context for vocabulary), (3) scanning for details, , (4) making inferences, and (5) finding references (locating references), and questions referring to the passage.

\subsection{The Concept of Teaching Materials}

According to the Ministry of National Education (2006: 5), teaching materials are materials or lecture materials that include knowledge (facts, concepts, principles, procedures), skills, and attitudes that learners must learn in order to achieve a defined standard of competence. The meaning of the teaching materials is similar to what Tomlinson (1998: 2) says, teaching materials is something that lecturers or students use to facilitate language learning, improve their knowledge and experience of language. Teaching materials display the whole figure of the competencies that will be mastered by students in lecturing activities.

\subsection{Criteria for Teaching Material Assessment}

In the preparation of teaching materials assessment criteria is very important to be used as the foundation. In general, the determination of the textbook writing criteria that often become the reference of many researcher of teaching materials development is the opinion of the study design experts such as the opinion of Reigeluth (1983), Tomlinson (1998), Brown (2001), and Moore (2005). While in the context of Indonesia referral area of the criteria of the assessment of textbook which is often used as the foundation is the National Education Standards Agency (BSNP), which is a national body containing experts who are tasked to assess the feasibility of textbooks to be published and used as textbooks both for textbook text Elementary school level as well as up to college textbooks. According to the National Education Standards Agency (BSNP), qualified textbooks must fulfill the four elements of eligibility, namely (1) content feasibility, (2) presentation feasibility, (3) language feasibility, and (4) picture feasibility. For lecturers, students, and the general public, this instrument can be used as a basis for developing or writing textbooks so that the results do not deviate from the expectations of BSNP. 


\subsection{English for Specific Purposes (ESP)}

English For Specific Purposes (ESP) is an approach in the teaching for specialized fields and studies that meet the needs of the English language proficiency and profession. The fields of science and professions such as English for law, medicine, mechanical engineering, economics, maritime and so on. This is as stated by ESP Hutchinson and Water "ESP is an approach to language teaching which is aimed at meet the needs of particular learners". This statement means that the content of learning matrix must be really needed by the learners (Hutchinson and Water, 1987:2). Thus, ESP's main focus is language skills related to specific needs or disciplines.

ESP experts such as Hutchinson and Waters (1987), Dudley-Evans and St. John (1998) agrees that ESP is classified into two, namely English for Academic Purposes (EAP) and English for Occupational Purposes (EOP). EAP is an English language taught to students for academic purposes or to understand certain subject areas, such as science and technology, medicine, economics, and studies of Islamic studies. A more concrete example is the language taught to students to understand the text or the English literature on Islamic studies classified into the EAP. EOP is an English language taught to students for professional / vocational / job support purposes. In this ESP classification EAP is used by researcher in this study as a frame of thought because it is in accordance with academic features that help students to understand the text or Islamic English texts.

Robinson (1991) divides ESP into two kinds, (1) English for Occupational Purposes (EOP), which consists of pre-experience, simultaneouss / in Service, and post experience and (2) English for Educational Purposes (EEP) / English for Academic Purposes (EAP), which consists of English for study in a specific discipline, and English as a school subject. The division of ESP Robinson is more able to accommodate English learning at IAIN Bengkulu than on the division of ESP Hutchinson and Waters (1987). English for IAIN students whose discipline of knowledge on Islamic religious sciences and the content of their English learning materials contains Islamic studies can be categorized into EEP / EAP Groups divided into English for study in a specific discipline and English as a school subject.

English at IAIN Bengkulu can be classified as EEP / EAP, which is English for discipline of certain field of knowledge, that is the field of Islamic science and also as one of MPK course taught at all of Faculties at IAIN Bengkulu. In this research EAP at IAIN Bengkulu is devoted to the English teaching at PAI study program of Tarbiyah Faculty. Therefore, reading comprehension material developed in this research is reading comprehension material in English II course for the third semester student of Study Program Islamic Religious Education Study Program. The design of IES-based reading comprehension materials is preceded by the implementation of need analysis study, which is the study of what English teaching material is really needed by the students of PAI Study Program of Tarbiyah Faculty of IAIN Bengkulu.

\subsection{Needs Analysis}

According to Basturkmen (2010:17), needs analysis is the identification of language and skills used in determining and selecting material in ESP-based learning. This analysis can also be used to assess the learner and the learning process at the end of the learning period. From Baturkman's statement it can be understood that needs analysis is an activity of gathering information related to the learners and their basic needs. Needs analysis is very useful to determine the 
direction of the learning program more precisely so that the effectiveness of the ESP program is increasing. This is, as stated by ESP experts such as Munby (1978), Hutchinson and Waters (1987) and Dudley-Evan and St. John (1998) that needs analysis is the first step that needs to be taken in the preparation of ESP English learning program. The results of the needs analysis are further used as the basis for syllabus design, selection and preparation of materials, teaching and learning process, and evaluation.

Hutchinson and Waters (1987) state that "needs" can be interpreted at least in three categories: (1) needs as necessities, (2) Needs as wants (desire); And (3) needs as lacks. Needs as necessities relate to what English needs to be known by the learners in order to play an active role in the language it learns. Needs as lacks, related to the early knowledge of English possessed by the learner, that is, what the learner has not learned yet. The findings on the lacks are very useful to determine the starting point of the teaching program so that it will create the effectiveness of the teaching program to achieve the target needs. While the needs as wants (desire) associated with personal goals is what is wanted.

Adhabiyyah et. al developed Graves' analysis model (2000) which summarizes needs analysis as a construct consisting of three components:

a. Target Situation Analysis (TSA)

b. Current Situation Analysis (CSA)

c. Learning Situation Analysis (LSA).

These three components can not be separated from the concept of needs analysis as described by Hutchinson \& Waters, where the needs analysis is developed with attention to three main aspects - necessities, lacks, and wants. TSA is everything the learner needs to do in the target situation. Hutchinson and Waters defined TSA as Necessities, Lacks, and Wants. Necessitiy is one of needs determined by the demand of the target situation, namely what learners need to know so that they can perform their work effectively within a targeted situation. Meanwhile the lack on the other hand is a gap that distinguishes what the learners already know with what they do not know so they need to explore in their learning process. This gap is what Jordan says in Adhabiyyah et. al. is the basis of the development of a syllabus which he later named as a deficiency analysis or analysis of deficiencies called CSA. It aims to provide information related to the de facto condition of the learners early in the learning period. It is important to know the progress of learning outcomes, but this is not possible if the initial condition of the learner is not identified first. From the above description can be concluded that the process needs analysis (needs analysis) is a complex activity that involves not learners in the target situation only. Both the target situation and the learning needs are two important components that need to be calculated in the needs analysis process. Thus a comprehensive needs analysis will include aspects of target situation analysis, discourse analysis, current situation analysis, learner factor analysis, and context analysis of teaching. 


\section{PREVIOUS RELEVANT STUDIES}

Some of the previous relevant studies relate to this study are as follows. First, research conducted by Ribahan under the title "Developing Reading Comprehension Materials for Students of Economics Department, State Institute of Islamic Studies, Mataram". The purpose of this research is to develop reading comprehension materials for students of Economics Department of IAIN Mataram. The product development is intended for students to comprehend English reference such as textbooks, journals, newspapers, magazines and other resources. From the experimental results it is concluded that this instructional material is effective to improve the reading comprehension of English text of UIN Mataram Economics students. Second, research conducted by Muhsinin entitled "Developing English for Islamic Studies for Students of Islamic Education Department of Mataram State Institute for Islamic Studies (IAIN Mataram). Research on the development of ESP English teaching materials for IAIN Mataram students by Muhsinin is concluded feasible and effective to be used as an English textbook at IAIN Mataram.

\section{METHODS}

To get the research objectives as mentioned above, this study was designed by using research and development method.According to Borg and Gall (1983:772), research and development is a process used to develop and validate educational products such as: syllabus, teaching materials, text books, research methods, and others were carried out in a cycle of research and development.Borg and Gall state the steps in the research as a development cycle that includes 10 stages, namely: (1) research and information collecting, (2) planning, (3) develop a preliminary form of the product, (4) preliminary field testing, (5) product revision play, (6) play field testing, (7) product revision operations, (8) operational field testing, (9) final product revision, and (10) dissemination and implementation. In this study the 10 steps recommended by Borg and Gall simplified into six phases as in the following table.

Table 1: Procedure on Developing Learning Materials Reading Comprehension Instructional Materials

\begin{tabular}{|c|c|c|}
\hline No & Development Phase & Rsearcher's Acitivity \\
\hline \multirow[t]{2}{*}{1.} & $\begin{array}{l}\text { Research and information } \\
\text { collecting }\end{array}$ & $\begin{array}{l}\text { 1. Need Analysis } \\
\text { a. Analyzing students' English learning needs } \\
\text { b. Curriculum analysis } \\
\text { c. Analyzing English teaching materials II that have } \\
\text { been usedd. } \\
\text { d. Analyzing students' characteristics }\end{array}$ \\
\hline & & 2. Identifying the problem \\
\hline 2. & Planning & $\begin{array}{l}\text { 1. Identifying some aspects found in } \\
\text { Standard Competence dan Basic Competence } \\
\text { 2. Identfying kinds of learningg materislas } \\
\text { 3. Mapping instructional materials } \\
\text { 4. Select teaching } \\
\text { 5. Chooseing source of teaching materials } \\
\end{array}$ \\
\hline 3. & Product development & Desgining teaching material prototyper \\
\hline \multirow[t]{2}{*}{4.} & Product validity test & 1. Validity test of prototype instrument \\
\hline & & 2. Validity test of developed product \\
\hline 5. & Product revision & Revising the product based on experts' suggestions \\
\hline \multirow[t]{2}{*}{6} & Product effectivity test & 1. Testing the practicality of developed product \\
\hline & & 2. Testing the effectiveness of depeloved product \\
\hline
\end{tabular}


The research instrument for collecting the data in this study include, questionnaires, and interview. Three questionnairs were used in this research. The first quetionnair was used to evaluate the English reading texts or English texbook currently used as handbook in English II course by the students of PAI and PGMI Department of Tarbiyah Faculty of IAIN Bengkulu. To evaluate the textbook the questionnair was administered to the students to obtain the data about their perseption on the quality of the English textbook viewed from material content, presentation, and language use.The second one was used to evaluate the quality of the prototype by the expert of teaching material, the expert of teaching media, and English lecturers of IAIN Bengkulu. The third questionnair was used to get the data about the students perception on the quality of the English teaching material developed by the researcher.

The data found from those expert after validating the instruction material developed by the researcher was used to classify the quality of the product. To determine the product quality, percentage formula was used. The percentage formula can be seen in the following table (Mustaji and Sugiarso, 2005;102).

Table 2: Product Quality Percentage

\begin{tabular}{cll}
\hline No & Percentage & Product Quality \\
\hline 1 & $81 \%-100 \%$ & Very Appropriate No Need Revision \\
\hline 2 & $66 \%-80 \%$ & Appropriate No Need Revision \\
\hline 3 & $56 \%-65 \%$ & Less Appropriate Needed Revision \\
\hline 4 & $0 \%-55 \%$ & Strongly Not Appropriate and Needed Revision \\
\hline
\end{tabular}

Interview was used in this study as additional data and information from English lecturers and students regarding the situation in teaching reading comprehension now. Interviews were also used as additional data found from those English lecturers in developing a model Islamic educational studies based reading comprehension instructional material through schema theory approach.All the data obtained from the expert of teaching material, media, English lecturers, and from the students through questionnaire were analyzed by using descriptive percentages.But the data found from quasi experimental methode were analyzed using t-tst statistical analysis.

\section{FINDINGS AND DISCUSSION}

5.1 Finding

\subsubsection{Students' Perceptions towards English Instructional Materials Currently Used}

a. From the material aspect, the majority of respondents (86\%) stated thatEnglish language teaching material currently used as their handbook in teching and learning process in English II course is not in accordance with what they expect and need.

b. From the aspect of presentation, the majority of respondents (92\%) also stated that English language teaching materials currently used is less systematic, lack of information regarding with the Islamiceducation , and the absence of photographs or pictures that can help and motivate them in understanding the reading text.

c. Respondents' perceptions on the aspect of language still dominates in option 1 and $2(82 \%)$ although there are few of the respondets also chose option 3. It means that the reading text in English textbookcurrently used by the 
students of IAIN of Bengkulu is still difficult to be comprehended by those students.

5.1.2 The Experts' (the expert of instructional material, the expert of media, and English lecturers) Responseson the quality of the model of Islamic Educational Studies Based Reading Comprehension Instructional Material through schema theory Approach developed by the researcher.

Based on questionnair given to the expert of instructional material and the expert of media, it can be stated that both of those experts classified that the quality of the English reading comprehension instructional material developed by the researcher in good category (B) in which the percentage of ideals, respectively 78, $9 \%$ and 80,\%. Meanwhile, according to English lecturers at IAIN of Bengkulu the quality of the teaching material is classified very good with the percentage of ideals $82,4 \%$.

5.1.3 The students' Response to the teaching materials developed by the researcher.

The students' response to the instructional materials developed by the researcher is classified in the positive category with a score of 68,9 out of a maximum score of 80 is ideal.

\subsection{Discussion}

The perception stated by the students that the English language teaching material currently used at IAIN of Bengkulu is not in accordance with the students' need caused by several factors. First, based on the researcher's interview with the outhors of the English texbook, the researcher found that the preparation of the text book is not based on the principles of development of teaching materials such as without beginning with the analysis of students' need. Second, after the English language teaching materials were prepared there was no validation from the experts neither the expert of English instructional material northe expert of media. The lack of relevance of the reading text composed in the English language teaching materials influenced towards the students' motivation that is low in studying English seriously. There is no explanation about the readability of the reading texts currently used by the students and their lecturer as the handbook in learning and teaching process of English II course.

Basically, although, the response from the expert of instructional material and the expert of media stated that the quality of the instructional materials developed by the researcher is in good category. Even, the English lecturers' response towards the Englis instructional material is very good quality. But those experts suggested that it would be better if the teaching material developed by the researcher could also be designed more modern with more sophisticated media such as CD and internet, so the students would not feel bored with one media only.

Refering to the students' responseto Islamic educational studies based reading comprehension instructional material developed by the researcher in positive category is due to several factors. First, the entire reading texts provided (16 reading texts) in the teaching materialare related to Islamic educational studies such as on: Islamic law, Islamic educational history, aqidah akhlak, Al-Qur'an and Hadith. All the content of the reading texts known by the students. It means that those students have schemata on Islamic educational studies. The schemata owned by the students on the content of the reading textscan accelerate the students in comprehending the content of the reading texts and can also increase students' 
motivation to read. Second, the readability of all the reading texts available in the teaching material developed by the researcher is the level grade 7-12 which is in accordance with the students' reading ability level for university student level.

\section{CONCLUSION}

Based on data analysis and some research findings as described in the previous pages, it can be drawn some conclusions as follows.

a. The perceptions of students toward the existing English teaching material: (1) the English reading texts analyzed from the aspectof material content is not in accordance with what expected and needed by students of PAI dan PGMI Department of Tarbiyah Faculty of IAIN of Bengkulu, (2) the English teaching reading text instrcutional material analyzed from the aspects of langugage presentation is still not systematic, lack of information regarding the Islamic educational studies, and there is no photographs or pictures that can help and motivate students in comprehending thosereading texts reading, and (3) all English reading texts available in the English textbook currntly used as the handbook for English II course at IAIN of Bengkulu analysed from readability analysis are not accordance with the students' reading ability level grade.

b. The quality of teaching material models based Islamic studies reading comprehension schema theory approach developed by the researcher provided for English II course for second semester students PAI Study Program of Tarbiyah Faculty of IAIN of Bengkulu in English II course is classified in good category, even, according to English lecturers of IAIN of Bengkulu, it is claassified in very good category.

c. The student response towards the model reading comprehension teaching materials based on Islamic educational studies developed by the researcher is classified in the positive category.

\section{REFERENCES}

Abdillah. 2003. Analisis Buku Rujukan Bahasa Inggris dalam Kurikulum Nasional Perguruan Tinggi Agama Islam untuk Fakultas Tarbiyah. Scholar Jurnal Pendidikan, 4 (1): 9

Adhabiyyah,R.Mahanum,and NorA.M.2014.Needs analysis and material development in English for specific Purposes in relation to English for IslamicStudies .E-proceedings of the Conference on Management and Muamalah(CoMM2014),26-27May2014. Synergizing Knowledge on Management and Muamalah (E-ISBN:978-983-3048-92-2)

Basturkmen,H.2010.Developing Courses in English for Specific Purposes. Hampshire: Palgrave Macmillan.

Borg. W.R. \& Gall, M.D. 1983.Educationnal Research:An Introduction. New York: Longman.

Busching, B.A. dan Schwartz, J.L. (1983). Integrating the Language Art in the Elementary School, Urbana, Illinois: National Council of Teachers of English

Depdknas. 2006. Pedoman Penulisan BukuPelajaran, Penjelasan Standar Mutu Buku Pelajaran Bahasa Indonesia. Jakarta: Pusat Perbukuan, Departemen Pendidikan Nasional. 
Dudley-Evans, Tony and Maggie Jo St John. 1998. Development in English for Specific Purposes: A Multy-disciplenary Approach. Cambridge: Cambridge University Press.

Dupuis, M.M. (1992). Content Area Reading. New Jersey, Engliwood Cliffs : Prince-Hall, Inc.

Farr, R. (1984). Reading: Trends an Challenges. Washington D.C.: National Education Association.

Hutchinson, T. and A. Waters. 1987. English Specific Purposes: A LearningCentred Approach. Cambridge, UK: Cambridge University Press.

Indrawati, Sri. 1996. Jurnal Ilmu Pendidikan. "Pengaruh Konteks Visual terhadap Pemahaman Bacaan Murid Sekolah Dasar". Malang: IKIP Malang

Munby, John. 1978. Communicative Syllabus Design, Cambridge: Cambridge University Press.

Mustaji dan Sugiarso. 2005. Pembelajaran Berbasis Konstruktivistik. Surabaya: UNESA University Press.

Nuttal, Christine. (1996). Teaching Reading Skills in a Foreign Language. Oxford: Heinemann.

Ricards, J. (1985). Longman Dictionary of Applied Linguistics. Hongkong : Longman Group Ltd.

Sharpe,P.2004.HowtoPreparefortheTOEFL:Test of English as Foreign Language: New York: Barron"s Educational Series, Inc.

Tomlinson,B.1998.Material Development in Language Teaching.Cambridge: CambridgeUniversityPress.

Zulkarnaini. 2009. Pembelajaran dengan Bahan Ajar Buatan Guru (http://zulkarnainidiran.wordpress.com/2009/06/28/pembelajarandengan-bahan-ajar-buatan-guru/) 